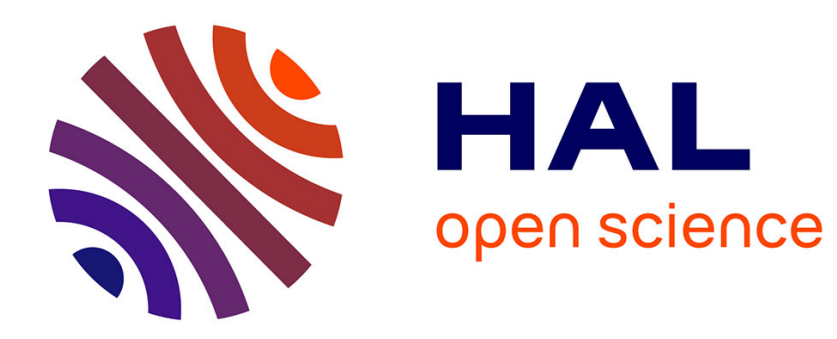

\title{
Similarity, comparison of equality and verbal manner demonstratives in Polynesian languages \\ Claire Moyse-Faurie
}

\section{To cite this version:}

Claire Moyse-Faurie. Similarity, comparison of equality and verbal manner demonstratives in Polynesian languages. Faits de langues, 2019. hal-02868689

\section{HAL Id: hal-02868689 \\ https://hal.science/hal-02868689}

Submitted on 15 Jun 2020

HAL is a multi-disciplinary open access archive for the deposit and dissemination of scientific research documents, whether they are published or not. The documents may come from teaching and research institutions in France or abroad, or from public or private research centers.
L'archive ouverte pluridisciplinaire HAL, est destinée au dépôt et à la diffusion de documents scientifiques de niveau recherche, publiés ou non, émanant des établissements d'enseignement et de recherche français ou étrangers, des laboratoires publics ou privés. 


\title{
Similarity, comparison of equality and verbal manner demonstratives in Polynesian languages
}

\author{
Claire Moyse-Faurie ${ }^{*}$
}

\section{INTRODUCTION ${ }^{1}$}

Polynesian languages (of which there are about 35) all belong to the Oceanic subgroup of the Austronesian family, forming one of the three branches of Proto Central Pacific, along with Fijian and Rotuman. They are spoken within what is called the Polynesian triangle, whose apices are Hawaii, New Zealand and Easter Island, as well as outside this triangle, in the neighbouring islands of Melanesia and Micronesia. Proto Polynesian (PPn) is characterised by numerous phonological and morphological innovations; it is divided into two subgroups (Pawley 1966, 1967), the Tongic subgroup to which Tongan and Niuean belong, and the Nuclear Polynesian subgroup to which all the other Polynesian languages belong.

Most Polynesian languages share numerous characteristics with other Oceanic languages, such as constituent word order (initial or median verb), complex pronominal systems distinguishing exclusive vs. inclusive forms for first persons, three numbers (singular, dual, plural), no gender distinction, and very few adjectives. Other characteristics are well-known as being specifically Polynesian, such as little differentiation between nouns and verbs, most lexemes being multifunctional. Western Polynesian languages have no passive voice, and most of their transitive verbs occur in ergative structures, except verbs of perception, emotion and communication which occur in accusative constructions. Eastern Polynesian languages are accusative, and have a passive voice.

Polynesian languages have a rich paradigm of demonstratives, essential for expressing localisation and spatial orientation and also, as this article will show, in comparative constructions. All the available data on these languages reveal the important role and richness of demonstratives. Few grammars, however, take into account the role of these demonstratives for expressing similarity and comparison of equality. For example, in an article on spatial deixis in Pileni, a Polynesian Outlier (now known as Vaeakau-Taumako) spoken in the Solomon islands (Næss 2004), and in the grammar of the same language (Næss \& Hovdhaugen 2011), nothing is said about the role of demonstratives in equative

*UMR 7107 (Lacito-CNRS), e-mail: claire.moyse@cnrs.fr

${ }^{1}$ I would like to thank Yvonne Treis and two anonymous reviewers for critical comments and stylistic improvements. 
comparison, whereas the latter publication does briefly mention comparison of inequality, performed with directionals (pp. 59 and 143). Dictionaries, however, contain manner deixis forms, such as pelāaphelā, penā/phen $\bar{a}$ '(be) like that' and penē/phene '(be) like this' (Hovdhaugen et al. 2002: 206-207), along with a few examples such as noho phenē! 'Sit like this!' (Hovdhaugen 2006: 106).

Other examples given in the Vaeakau-Taumako dictionary illustrate the multifunctionality of these words, as both nominal and verbal determiners and main verbs, expressing comparison of equality and similarity. These manner verbs are complex forms, including the morpheme pe-/phe- 'like' and a demonstrative ( $\bar{l} \bar{a}$ 'that, those', $n \bar{a}$ 'that, those' and $n \bar{e}$ 'this, these').

All the Polynesian languages for which data is available, of whatever subgroup, attest such complex forms, the so-called verbal manner demonstratives, along with verbs of resemblance, mainly used to express similarity and comparison of equality.

Each of these verbs covers specific semantic domains (historical or physical resemblance, similitude in behaviour, complete identity, manner deixis, etc.).

Section 2 presents verbs of resemblance and similarity in East Uvean. Section 3 closely examines manner demonstrative verbs in several other Polynesian languages, showing their formal variety and their multifunctionality in related semantic domains. Section 4 presents similative constructions with a standard marker. Section 5 shows that, unlike European languages, comparison of degree (that is, comparison of superiority or inferiority) in Polynesian languages is expressed by means of quite different constructions than the ones used for comparison of equality and similarity.

\section{QUALITATIVE COMPARISON}

According to Haspelmath \& Buchholz (1998: 313), "similatives express identity of manner, whereas equatives express identity of degree or extent, or in other words, similatives express quality while equatives express quantity". Differentiating between qualitative and equative comparison, however, is not an easy task in Polynesian languages because, as we will see, the same verbs and constructions can be used for both types. We will first present different verbs of resemblance, identity and difference.

\subsection{Verbs of resemblance in East Uvean}

East Uvean (known as Faka'uvea by the speakers) has several verbs of resemblance, denoting either physical similarity or similitude of behaviour. With the verbs agaaga 'behavioural resemblance' (1), hoko 'global resemblance' (2) and föliga 'partial physical resemblance' (3), the standard of comparison is expressed as a prepositional phrase, introduced by the polyfunctional dynamic "oblique" preposition ki (glossed DYN in this article) occurring as a standard marker in these comparative constructions. 
East Uvean ${ }^{2} 3$

(1) 'E agaaga te kiú ki te veká. NPST resemble SPC sea.lark DYN SPC banded.rail 'The sea lark behaves like the banded rail (Gallirallus philippensis.' (MoyseFaurie 2016: 136)

(2) 'E hoko te tamá ki tana matu'á. NPST resemble SPC boy DYN POSS3SG father 'The boy resembles his father.'

(3) 'E fōliga te ta'ahiné ki tona tu'aga'ané. NPST resemble SPC girl DYN POSS3SG brother 'The girl has the same facial expressions as her brother.'

Besides, in East Uvean, both similarity and comparison of equality can be expressed by the same verb, hage 'be so, be similar', occurring in different constructions whether the parameter of comparison is expressed or not.

As far as similarity of appearance or physical resemblance is concerned, no specific parameter is expressed, just pure resemblance expressed by the verb, and the standard of comparison occurs as a nominal clause introduced by the predicative marker ko, irrespective of whether the comparee is omitted (4), as is often the case with $3^{\text {rd }}$ singular pronominal absolutive argument, or expressed (5):

East Uvean

(4) 'E hagē ko te 'ū mata o te tuná. NPST resemble PRED SPC COLL eye POSS SPC eel '[He] looks like the eyes of an eel.' (Moyse-Faurie 2016: 255)

(5) 'E ke hagē koe ko ia. NPST 2SG resemble 2SG PRED 3SG 'You look like him.'

The predicative marker can be omitted when the standard of comparison is a nominal phrase, following a pronominal comparee:

East Uvean

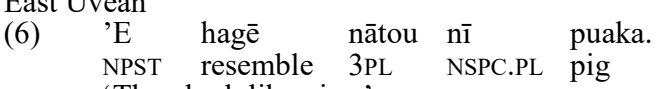
'They look like pigs.'

\footnotetext{
2 Data not identified for source is taken from my own fieldnotes.

3 Abbreviations (other than those following the Leipzig glossing conventions): ANAPH anaphoric, APP appositive, CFUGE centrifugal directional, COLL collective, DEIC deictic, DIST distal, DYN dynamic centrifugal preposition, EMPH emphatic/demarcating particle, IMM immediate aspect, INC inceptive, INCH inchoative, MED medial, NSPC non-specific article, NUM numeral predicative, POc Proto Oceanic, PNP Proto Nuclear Polynesian, PPn Proto Polynesian, RED reduplicate, RESTR restrictive particle, SPC specific article, STAT static preposition, SUCC successive aspect, TRANSV transverse, VENT ventive.
} 
In addition, equative comparison has a nominalised parameter (lele 'run' in (7), lahi 'tall' in (8)); the comparee is then expressed as the possessor of the parameter:

East Uvean

(7) 'E hagē pē tau lele ko te lele a he pusi. NPST resemble RESTR POSS2SG run PRED SPC run POSS NSPC cat 'You run like a cat.' (Lit. your run resembles the run of a cat)

(8) 'E hagē ko Pētelō tona lahi. NPST resemble PRED Petelo POSS3SG tall

'He is as tall as Petelo.' (Lit. [he] resembles it is Petelo his height)

This East Uvean verb is formally identical to the Tongan form (Churchward 1953), from which it has certainly been borrowed since it is not attested in other Nuclear Polynesian languages.

\subsection{Identity}

2.2.1. Identiity expressed with a specific verb : In East Uvean, exact identity or similarity is expressed with the adverb tatau 'same, identically' ${ }^{4}$ postposed to a verb, expressing the parameter of comparison. The comparison can be quantitative (9) or qualitative (10). The restrictive particle $p \bar{e}$ underlines the identity of the comparees, and the two comparees are coordinated with the phrasal coordinator mo 'and, with'.

East Uvean

(9) 'E mama'o tatau pē ia Mala'efo'ou mo Vailala mai Matā'utu. NPST far same RESTR ABS Mala'efo'ou and Vailala from Mata'utu 'Mala'efo'ou and Vailala are the same distance from Mata'utu.'

(10) 'E popoto tatau pē ia Soane mo Pētelō. NPST intelligent.PL same RESTR ABS Soane and Petelo 'Petelo and Soane are similarly intelligent.'

In East Futunan, the neighbouring language, tatau occurs as a plain verb, used as parameter. The two comparees may be expressed in a single noun phrase (11), or coordinated with the disjunctive conjunction pe 'or' (12). (See below $\S 4$ for other uses of East Futunan pe.)

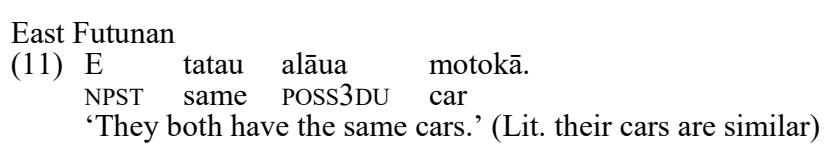

4 PPn *(ta)tau 'to match', 'equal', 'the same as' (Ranby 1980) is widely reflected in Polynesian languages. 
(12) E se tatau a ma'uga o Futuna pe ma'uga o Falani. NPST NEG same ABS mountain POSS Futuna or mountain POSS France 'Mountains in Futuna do not look like mountains in France.' (Lit. the mountains of Futuna or the mountains of France are not identical)

As seen in (12), non-identity can be expressed in a negative construction. It can also be expressed with a specific verb, such as kese '(be) different', as shown in the two following East Futunan examples.

- The standard of comparison can be introduced by the oblique stative preposition $i(13,14)$ :

East Futunan $\begin{array}{lllllll}\text { (13) } & \text { E } & \text { kese } & \text { lou } & \text { gā } & \text { kie } & \text { i lo'oku. } \\ \text { NPST } & \text { different } & \text { POSS2SG CLF } & \text { loincloth } & \text { STAT mine }\end{array}$ 'Your loincloth is different from mine.'

(14) E kese a ia i leia le toe la. NPST different ABS 3SG STAT DIST SPC child EMPH 'He is different from that child over there.'

- Or the standard of comparison can be introduced by the phrasal coordinator mo 'and, with' (15):

East Futunan

$\begin{array}{lllll}\text { (15) } & \text { E } & \text { kau } & \text { kese mo } & \text { koe. } \\ \text { NPST } & 1 \text { SG } & \text { different with } & \text { 2SG }\end{array}$

'I am different from you.'

2.2.2. Identity expressed with the numeral 'one': The numeral 'one' is used to express strict similarity, leading to a complete identity of the comparees. In (16), the East Futunan numeral tasi 'one' expresses the fact that the two comparees have the same mother (16):

East Futunan

(16) Ko Soane mo Paulo e tinana tasi kae tamana kesekese.

PRED Soane andPaulo NPST mother one but father different.PL,

'Soane and Paulo have the same mother, but their fathers are different.'

In Tahitian, both tahi 'one', a reflex of Proto Nuclear Polynesian (PNP) *tasi, and $h \bar{o} ' \bar{e}$ 'one, any', a lexical innovation, can express equative comparison. In this context, both forms are usually followed by the continuative aspect $\bar{a}$ 'still':5

Tahitian

(17) Tahi ā tō'u mana'o 'e tō'oe.

one DUR mine thought and yours

'I think the same way as you do.' (Lit. still one mine thought and yours) (Coppenrath \& Prevost 1975: 168)

5 The co-occurrence of a verb used in comparison and the continuative aspect is also mentioned in Marquesan (Cablitz 2006; cf. §3.2.2) 


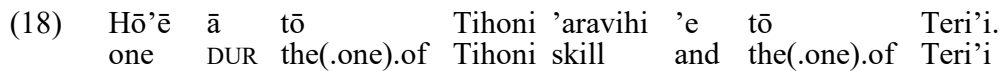

'Tihoni is as skillful as Teri' i.' (Académie tahitienne 1986: 59) ${ }^{6}$

\section{VERBAL MANNER DEMONSTRATIVES}

This section presents other verbs occurring in qualitative comparison, with a focus on manner comparison, rather than quality or degree. All the deictic manner verbs include a demonstrative form, but the other components as well as their number, differ depending on the language.

\subsection{Number of the verbal manner expressions}

Until very recently, little was known about verbal demonstratives in the Pacific languages. For example, Dixon (2003: 88) writes: "I know of only two languages with verbal demonstratives - Boumaa Fijian and Dyirbal - and in each instance there is just one verb 'do it like this' (with transitive and intransitive variants in Dyirbal). Further work may well reveal a language with a contrast between two verbal demonstratives, but I suspect that most languages which show this category will have a single item."

Consequently, Dixon only lists one demonstrative verb in Boumaa Fijian, 'eneii 'do like this'. But in fact, in his Grammar (1988), the author explains that the verb 'eneii can be followed by any of the demonstratives. In example (19), it is the distal demonstrative which follows the manner verb:

Boumaa Fijian (Dixon 1988: 61)

(19) E 'eneii-mayaa a 'e-na i-va'a-rau i Taveuni.

3SG do.like-that ART CLF-3SG custom on Taveuni

'That's the way the customs (of greeting a visiting high chief) are carried out on Taveuni.'

More recently, Guérin (2015) published an entire article on demonstrative verbs. Surprisingly, she doesn't mention Samoan or any other Polynesian language, which offer many examples of verbal demonstratives, most of them being products of relexification processes. Her article offers a thorough analysis of demonstrative verbs and verbal manner deixis, but some of her conclusions will have to be revised in the light of Polynesian languages.

Several descriptions of Polynesian languages, however, do take verbal demonstratives into account, though not always under the same label. In their Samoan grammar, Mosel and Hovdhaugen (1992) mention four Samoan "deictic verbs", listed below with slight differences in their meanings, but with the same designative terms as in Mosel (2004: 149-150):

${ }^{6}$ Many thanks to Jacques Vernaudon who sent me the glosses for the Tahitian examples, not given in the publications. 
Samoan (Mosel \& Hovdhaugen 1992: 135)

(20) fa'apea '(be, do, say, think) like this/that (cataphoric and anaphoric)' fa'apēnei '(be, do, say, think) like this (cataphoric)' fa' apena ' '(be, do, say, think) like this (anaphoric)' fa' apelā '(be, do, say, think) like that (far away)'

The predicative use of the verbal demonstrative fa' apea is shown in (21):

(21) Tigilauma'olo 'o le à le mea 'ua fa'apea ai 'oe? Tigilauma'olo PRED SPC what SPC thing PFV do.like.that ANAPH 2SG 'Tigilauma'olo, why are you like that?' (Mosel \& Hovdhaugen 1992: 136)

Leaving aside the interrogative verb '(be) how' for the moment (see §3.6), we have seen that Samoan has four verbal demonstratives, whereas in East Futunan, there are only three:

East Futunan

(22) fene'eki 'être ainsi (comme le locuteur, comme ce qui suit)' ['(be) like this' (proximal: near speaker)]

fena'aki, 'être ainsi (comme l'interlocuteur)' ['(be) like that' (medial: near addressee)]

fela'aki, 'être ainsi (comme une tierce personne)' ['(be) like that' (distal: near neither or near a third person)]

In Grézel's East Futunan dictionary (1878: 125-126), the three forms felaaki, fenaaki (both translated as 'ainsi, comme cela, de cette sorte, de cette manière') and feneeki are given, but preceding feneeki, the form fenei-no longer attested is also mentioned: fenei, feneeki 'ainsi, comme ceci, de cette manière-ci'.

In East Uvean, according to Bataillon (1932), the three verbal manner demonstratives are fênei 'être ainsi comme ceci', fenā and fêia 'être ainsi comme cela', sometimes occurring as predicates followed by an absolutive argument, but more often as adverbs.

Besnier (2000: 224-226; 411-414) offers a thorough description of the three Tuvaluan "demonstrative verbs and adverbs": peenei 'thus' (near speaker), peenaa 'thus' (near the addressee), peelaa 'thus' (away from speaker and addressee). And indeed, most Polynesian grammars and dictionaries do mention these manner verbal demonstratives, though variously labelled.

The following section examines the morphological structure of these lexicalised expressions, which encode at least a deictic component, indicating the distance from speaker and addressee (proximal, medial, distal) and an ontological one, the manner '(be) like' component.

\subsection{Different components of verbal manner demonstratives}

According to Dixon (2003:72), “A fair number of languages have a second type of adverbial demonstrative, with a manner meaning, 'like this, in this way/manner'; these are generally non-inflecting, and serve to modify the verb of the clause. They are in most cases derived from the nominal demonstratives". 
This is indeed the case with Polynesian verbal manner demonstratives, which not only occur as adverbials, but also as main verbs, and their deictic components are generally a reduced form of the nominal demonstratives: there are formal overlaps between nominal demonstratives and manner deictic expressions.

3.2.1. The deictic component: Polynesian verbal manner demonstratives vary in form, as far as the first component is concerned, but all of them are based on nominal demonstratives: their morphological structure includes at least a deictic component (cf. Senft ed. 2004), indicating the distance from speaker and addressee (proximal, medial, distal) and an affix. In Polynesian languages, (ad)nominal demonstratives, most often appearing in a noun phrase with a noun, and in some languages with a pronoun, may also make up a complete noun phrase (the 'demonstrative pronoun' function). Table 1 below lists East Futunan demonstratives, as they occur in noun phrases.

Table 1: East Futunan demonstratives

\begin{tabular}{|l|l|l|}
\cline { 2 - 3 } \multicolumn{1}{c|}{} & \multicolumn{1}{c|}{ singular } & \multicolumn{1}{c|}{ plural } \\
\hline proximal & leinei & anei \\
distal & len $\bar{a}$ & ana $\bar{a}$ \\
anaphoric & leia & alā \\
aia & an $\bar{a}$ \\
\hline
\end{tabular}

The position of the proximal, medial and distal demonstratives may vary:

East Futunan

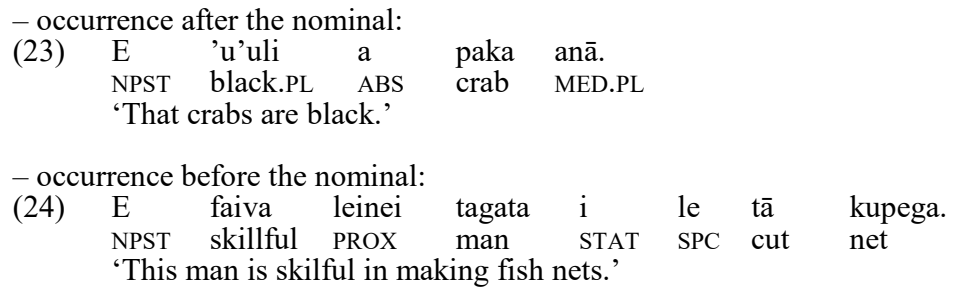

The forms occurring in verbal manner demonstratives are reduced:

- proximal -ne-

- medial $-a$ -

- distal -la-

According to Mosel (2004: 150), what I call "verbal manner demonstratives", "...cannot be classified as demonstratives because they do not refer to entities, but express how something is done or what someone thinks or says".

Indeed, expressions of manner deixis accompanied by appropriate gestures typically refer to a complete situation. As noted by König (2015), this quality also manifests itself in the anaphoric use, where they are substituted for a full clause or sentence. 
Still, the term "deictic verbs", which Mosel (2004) and Mosel \& Hovdhaugen (1992) employ, is potentially confusing since it is most often used for verbs of motion such as English go/come, German gehen/kommen and French aller/venir. Moreover, both verbal manner demonstratives and nominal demonstratives point to the real world, and their meaning is determined by situational context. See $\S 3.4 .2$, however, for examples of verbal manner demonstratives being used as nominal demonstratives.

Let us consider now the 'like' component of these verbal manner expressions, in addition to the deictic component.

3.2.2. The 'like' component: Listing the components for Samoan verbs, Mosel (2004) mentions "a synchronically not identifiable syllable -pe/pe- which seems to be cognate with pei "like"'. In the last Pollex-on-line version (Greenhill \& Clark 2011), only the PPn form *pe 'be like', along with three compounds *pēheni 'be like', *pē-hena 'be like that (near you)' and *pē-hera 'be like that' are given. In PNP, another form, *fēe, is reconstructed, reflected as $f e / f \bar{e}$ in East Futunan and East Uvean, in Māori as whe (along with $p \bar{e})$, and in Tokelauan as $v \bar{e}$. According to A. Pawley (p. c.), these forms could reflect another PPn etymon, *pehē 'be like'.

However, $p \bar{e}$ is also the Hawaiian form, found in four demonstrative verbs (as in Samoan): $p \bar{e}-n e i$ 'like this', $p \bar{e}-i a$ 'like that (indefinite)', $p \bar{e}-n \bar{a}$ 'like that (near the addressee)' ${ }^{\prime}$ and $p \bar{e}-l \bar{a}$ 'like that (far)' (Elbert \& Pukui 1979: 114). As already mentioned, a $p \bar{e}$ form is also found in Tuvaluan (Besnier 2000) as well as Marquesan: according to Cablitz (2006: 110-111), what she calls "deictic verbals", consist of the bound morpheme $p e$ ' $e$ - 'do like' denoting the manner of doing something, the three demonstratives nei, na and ' $a$, and the adverbial ana expressing continuous or progressive action. Cablitz notes that "it is not clear what the difference between pe'ena and pe'eana is". She only gives one example, with the "deictic verb" pe'enei, a cataphoric use of the proximal verbal manner demonstrative verb (25):

Marquesan

(25) Pehea taia kata? Pe'enei.
how POss3sG laugh be.like.PRox
'How does he laugh? - Like this.' (Cablitz 2006: 110, from Zewen 1987: 95)

For Māori, Bauer (1997: 271-273) describes "Deictic Pro-verbs": $p \bar{e}-+$ a deictic (nei, $n \bar{a}, r \bar{a})$, along with the interrogative $p \bar{e}(w) h e a$ 'how?'. They are also used for equality of degree (ibid.: 417-421), but in all the examples given in the grammar, only $p \bar{e}-r \bar{a}$ is present.

\footnotetext{
${ }^{7} \mathrm{PPn}$ *pehē, the Protoform suggested by A. Pawley (p. c.) is reflected as Tongan pehe 1 . 'like this, like that, thus'; 2 . 'to say, to think'. Tongan also attests pehena 'like that', peheni 'like this' (Churchward 1953: 150) and pehe'i (ibid.: 159). PPn *h is generally lost in PNP except in Tongan loans in East Uvean.

${ }^{8}$ The $p \bar{e}-n \bar{a}$ form is said to be obsolete.
} 
3.2.3. Other components: Polynesian languages differ as far as the first component is concerned. In addition to the 'like' and 'demonstrative' components, Samoan has a specific manner component: $f a^{\prime} a_{-}<\mathrm{PPn} *$ faka-, which has two main uses: the causative prefix and as an adverbial in the manner of'. The East Futunan verbal manner demonstratives include the prefix $f e$-along with an -'aki suffix. The presence of this suffix calls into question the etymology and meaning of the supposed 'like' prefix $f e$ - in East Futunan, since in this language, as in several other Polynesian languages, the $f e$ - prefix also marks a plurality of events, and is part of the circumfix $f e-\ldots$ - 'aki, the reciprocal/sociative marker.

Hence, in Samoan $f a^{\prime} a-$ and East Futunan fe-...'aki, verbal manner demonstratives have included forms with quite different functions. The semantic links, however, between the adverbial function of Samoan $f a$ ' $a$ - and the East

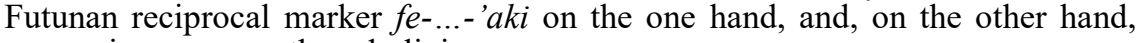
comparison, are worth underlining.

\subsection{Main uses of verbal manner expressions 'do it like this/that'}

The syntactic and pragmatic functions encoded by the verbal manner demonstrative expressions also deserve attention. Dixon (2003: 61) lists three different uses for verbal demonstratives: they may have a deictic reference to an activity, an anaphoric function, or introduce direct speech. Indeed, they are always polyfunctional, and can occur as verbal predicates, adverbs, connectives, quotative and optative verbal markers, nominal modifiers, and are cognate with interrogative verbs of manner ('be how?').

3.3.1. Similarity and equative comparison: When only the similarity of manner is expressed, the standard of comparison is simply implicit in the manner verb, and the comparee is the subject, pronominal $(26,27)$ :

Samoan

(26) 'Ua sau fua ia pēlā e vala'aulia.

PFV come just 3SG like.that NPST call.TR

'He just came as if he had been invited.' (Mosel \& Hovdhaugen 1992: 136)

East Uvean

$\begin{array}{lllllllll}\text { (27) Ko'é 'e } & \text { ke } & \text { feeia? } & \text { Ko te } & \text { kua } & \text { 'ilo'i } & \text { o } & \text { te } & \text { logó. } \\ \text { why NPST } & \text { 2SG } & \text { be.like.DIST } & \text { PRED SPC } & \text { PFV } & \text { know } & \text { POSS } & \text { SPC } & \text { news }\end{array}$

'Why are you like that? - It is because I heard the news.'

Or the comparee may be a definite nominal subject argument $(28,29)$ :

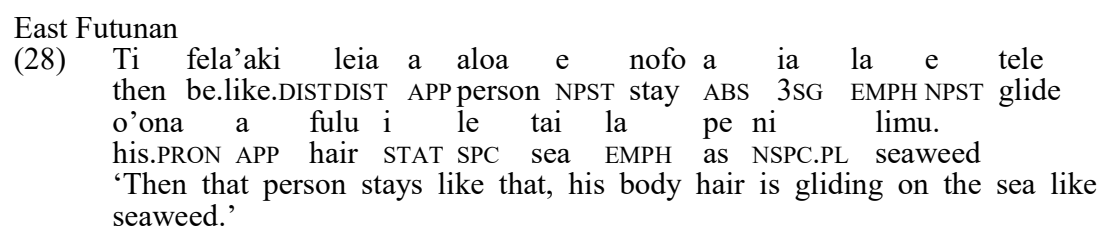


(29) Fena'aki lona faka'ilo'ilo e le puaka la ki ai. be.like.MED POSS3SG information ERG SPC pig EMPH DYN ANAPH 'So were the instructions given by the pig.'

If the comparee is indefinite, no overt subject is expressed $(30,31)$ :

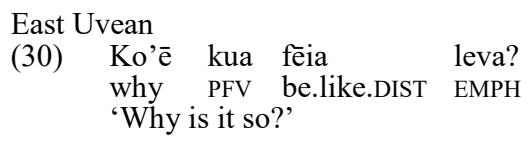

East Futunan

(31) Fene'eki ake loa apogipogi kuafano a Koletā i le vakalele. be.like.PROX UP SUCC tomorrow PFV leave ABSKoleta STAT SPC plane 'So, tomorrow, Koleta will have left on the plane.'

These verbal manner demonstratives can express equality in different types of construction, just as the ones described with verbs of resemblance.

- The standard of comparison can be introduced by an oblique preposition, with the comparee expressed as the possessor (32):

Māori (Bauer 1997: 417)

$\begin{array}{lllllll}\text { (32) } & \text { (I) pērā tonu ōna wae } & \text { i } & \text { oku } & \text { te } & \text { nunui. } \\ \text { (TAM) like.DIST EMPH POSS3SG } & \text { foot } & \text { STAT POSS1SG } & \text { SPC } & \text { big } \\ \text { 'His feet are just as big as mine.' } & & & & & \end{array}$

- The equative comparison construction can include a nominalised subject argument expressing the standard of comparison, while the comparee is again expressed as its possessor $(33,34)$ :

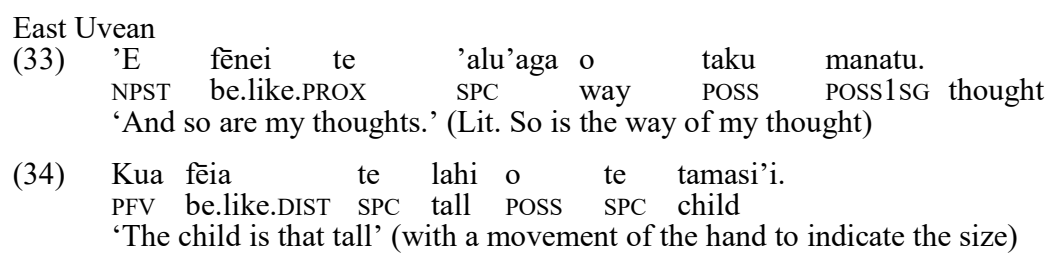

3.3.2. Quotative: The development of quotative markers from manner demonstratives is a well-known and wide-spread phenomenon. As noted by Dixon (2003: 102-103): "The verbal demonstratives are also used to introduce or conclude direct speech [...] In this function they should be used with a verb of speaking [...] In practice, the verb of speaking is generally omitted in texts, with the verbal demonstrative taking on the whole role of marking direct speech [...] A verbal demonstrative may be used to refer to other kinds of noise."

East Futunan and East Uvean verbal manner demonstratives can have endophoric uses related to direct speech that precedes them (anaphoric) or follows them (cataphoric) (35). 
East Futunan

(35) Fene'eki loa lana tagi la...

be.like.PROX SUCC POSS3SG cry EMPH

'She cries in such a way: ...'

In most cases, the direct or indirect speech occurs in past-tense sentences, and it is then the distal verbal demonstrative that is used (36); but I have also found a few examples with the proximal verbal demonstrative in a past tense sentence (37).

East Futunan

(36) Ti fela'aki loa a ne'a a le finematu'a la aia then be.like.DISTSUCC ABS thing POSS SPC old.woman EMPH ANAPH Sina ku tā kaku loa ki le ne'a leia na kau Sina PFV 1DU.INCL reach SUCC DYN SPC thing DIST PST 1SG māsau atu kiate koe la. speak CFUGE DYN 2SG EMPH 'Then the old woman said: Sina, you and I reached the point I had told you about!'

(37) Ko le ika a kotou Sigave na fene'eki lona toso PRED SPC fish POSS 2PL Sigave PST be.like.PROX POSS3SG drag mo lona lau na sua. with POSS3SG song PST sing

'This is your fish, to you the Sigave people, this was the song you were singing while hauling them.' (Lit. [...] was like this the dragging with the song accompanying it)

3.3.3. Optative: An optative construction always includes the distal verbal manner demonstrative, East Futunan fela'aki (38), East Uvean fêia (39), in combination with the up (East Futunan ake) or transverse (East Uvean age) directional.

East Futunan

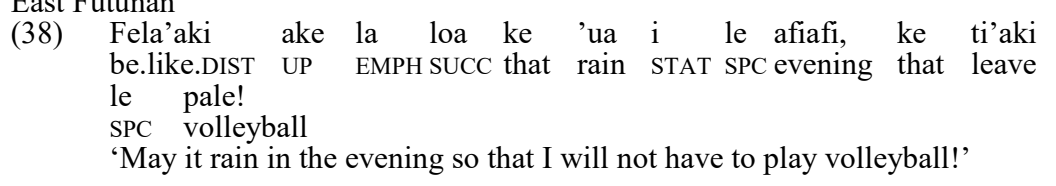

East Uvean
(39) Ke fêia age lā 'e olo atu te tautēhina that be.like.DIST TRANSV EMPH NPST go.PL CFUGE SPC two.brothers 'e tu'u mai he fusi momoho!
NPST stand VENT NSPC banana.tree ripe
'May the two brothers find on their way banana trees full of ripe fruit!'

The directionals occurring after the manner demonstrative verbs in optative sentences are more usually used in comparative constructions of degree, after the comparand verbs (cf. §5). 


\subsection{Other uses of verbal demonstratives}

3.4.1. Adverbial use: The verbal manner demonstratives can occur in an adverbial position, as the second verb in a serial verb construction (40-43):

East Uvean

(40) 'Ave fenā te laupapá.
take.away be.like.MED SPC table
'Take away the table that way.'

(41) Ne'e palalau fēnei te tēpitē.

PST talk be.like.PROX SPC deputy

'The deputy spoke this way...'

(42) Fakalelei he ko au ko te fakalakalaka fềia atu. excuse because PRED 1SG PRED SPC go.along, be.like.DISTCFUGE 'Excuse me, I am just passing along (in such a way).'

East Futunan

(43) Ti ulu mai fa'i leia o ulu fela'aki ti patā le then enter VENT RESTR DIST COMPenter be.like.DIST then hit SPC la'akau ki le fă'ulu o mate. wood DYN SPC head COMP die

'And when someone else comes in the same way, he is knocked on the head with a piece of wood and dies.'

3.4.2. Nominal demonstrative use: Curiously, the verbal manner expressions can occur as nominal determiners, most often after a nominal meaning 'thing', 'person'. 9 This adnominal use mainly expresses the surprise of the speaker (4447).

East Futunan

(44) Natu a veka o tio ki le ne'a fela'aki, kalaga mai... approach ABSrail COMP see DYN SPC thing be.like.DIST call VENT 'The rail bird comes near to look at such a thing [the giant clam], and calls...'

(45) Aloa, koleāle ne'a fene'eki kua fai e le fenua, ku lotou man why SPC thing be.like.PROX PFV make ERG SPC people PFV 3PL vesi'aki le mālō, ku lotou fia fai ki lelavā? hate SPC victory PFV 3PL feel.like make DYN SPC defeat 'Man! Why people are acting like this, do they hate to win, do they prefer to lose?'

(46) Ti natu a ia o tiotio, koi tio la a ia ki then arrive ABS 3SG COMP RED.see PROG see EMPH ABS 3SG DYN le la'akau fela'aki i Futuna nei. SPC tree like.DIST STAT Futuna here

'He comes to observe a little and stays looking at such a tree [still unknown] in Futuna.'

9 cf. Rapanui, where demonstratives are often preceded by what Du Feu (1996: 145) calls a "dummy" word, me'e 'thing': me'e nei 'this', me'e ena, me'e era 'that'. 


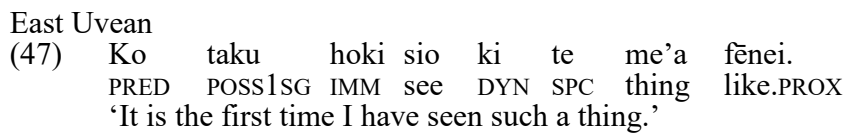

According to Bauer (1997: 421), a similar use of manner demonstratives is attested in Māori.

3.4.3. End of list use : Finally, verbal manner demonstratives occur as an end of list marker, expressing the meaning 'and similarly', 'etc.' (48).

East Futunan

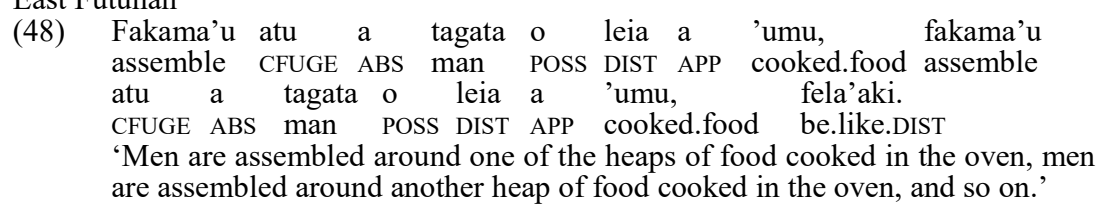

This end of list use recalls some of the English uses of so as shown in the translation of (48).

\subsection{Valency of the demonstrative verbs and their derived forms}

In Samoan, a language in which the verbal demonstrative always includes the $f a$ ' $a$ - prefix, the verbs are said to be non-ergative (Mosel \& Hovdhaugen 1992: 135). In East Futunan, the verbal manner demonstratives can optionally be derived with the cognate faka-prefix, and this derivation has no impact on the verb valency.

East Futuna

(49) Ko le koga lenā na kau 'aga o fai atu la na kau PRED SPC part MED PST 1SG start COMP do CFUGE EMPH PST 1SG manatu fa' $i$ ke fakafela'aki kae na le'esemanatu loa au. think RESTR that FAKA.be.like.DIST because PST NEG think SUCC 1SG 'The bad thing I have done to you, I really think that I have acted so without meaning to.'

The difference between the non-derived and the derived verb is still hard to define since both forms can occur in exactly the same context, in a cataphoric function $(50,51)$ :

East Futunan

(50) Tagi loa a koe o fakafene'eki lau tagi la: ... cry SUCC ABS 2SG COMPFAKA.be.like.PROX POSS2SG cry EMPH 'You will cry this way: ...' (Lit. you will cry so that your cry will be like this)

(51) Kaku atu loa a le fakavesili kia lāua la ti arrive CFUGE SUCC ABS SPC question DYN 3DU EMPH then 
fene'eki loa alāua a tagi: ...

be.like.PROX SUCC POSS3DU APP cry

'When they are questioned, they cry like this: ...' (Lit. arrive the question for them, and (it) is like this their cry)

Moreover, the derived form can also occur as a nominal demonstrative, a function not affected by transitivity $(52,53)$ :

East Futunan

(52) $\mathrm{Ti}$ ko leinei kua 'au a koe i le potu fakafena'aki then PRED PROX PFV come ABS 2SG STAT SPC place FAKA.be.like.MED ti e ko le tonu e tasi e tonu ke fai ke ti'aki then NPST PRED SPC right NUM one NPST right that do that leave ne'a fuli kae ano tāua. thing all but go 1DU.INCL

'Then, you were right to come to such a place, there is only one right thing to do: leave everything and both of us will go.'

(53) Kae na se faka'ilo kia Tu'i Sa'avaka mo le kakai leia but PST NEG announce DYN Tu'i Sa'avaka and SPC people DIST na fai fale la e iai se ne'a fakafela'aki kua PST build house EMPH NPST exist NSPC thing FAKA.be.like.DIST PFV soko.

happen

'But no one has told Tu'i Sa'avaka and the people over there who were building houses that such a thing had happened.'

In East Uvean, unlike Samoan, the verbal manner demonstrative can have an ergative argument, introduced by the ergative preposition $e(54)$ :

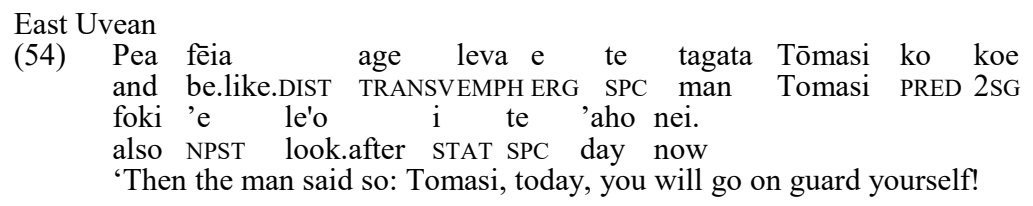

Hence, the faka-prefix at work in the above examples has no transitivising function. As mentioned earlier in this section when discussing the first component of the verbal manner demonstratives in Samoan, this prefix ( $f a^{\prime}$ ' $a$ - in Samoan) also has an adverbial function, conveying the meaning 'in the manner of' when combined with a nominal or locative noun, as is also the case with East Futunan fakafutuna 'in the Futunan way'. Preceding a verbal manner demonstrative, it simply conveys the point of view of the speaker/the deictic centre, on the way the event is realised.

In Tuvaluan, according to Besnier (2000: 224), the underived demonstrative verb can also enter a transitive construction: "A demonstrative in pee- can serve as the main verb of the clause, in which case it takes as a subject the noun phrase referring to the entity being equated and as optional object the standard of equation" (55): 
Tuvaluan

(55) Koo peelaa mo koo taumafai o ofa nee ia te INC be.like.DIST COMPINC try COMP break ERG 3SG SPC vaa llei o taaua. gap good POSS 1DU.INCL

'It's as if he were trying to break the good rapport that you and I have.' (Besnier 2000: 224, glosses slightly adapted)

In conclusion, the examples presented in this section show the high valency variation of the verbal manner demonstratives depending on the language.

\subsection{Link with interrogatives}

According to Diessel (2003) and Dixon (2003: 77), "in a number of languages, interrogatives fall into the same paradigm as demonstratives". This is the case in Polynesian languages for the manner interrogative verbs '(be) how', which show the same components as the verbal manner demonstratives, except the deictic ones (56).

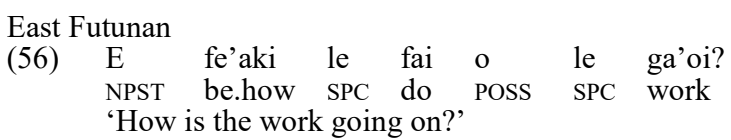

In East Futunan, the interrogative verb may be partly reduplicated. It can occur as predicate (57) or as adverb (58), the sentences having similar meanings:

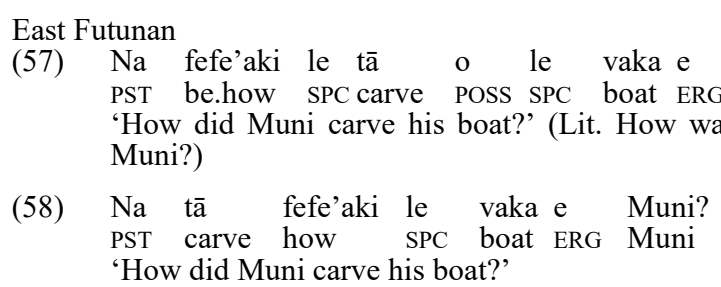

In Tuvaluan, the interrogative verb '(be) how' is pēfea (lit. like where/which), and has the same components as cognate forms in East Uvean, in which the interrogative verb feafea' $i$ 'be how?' consists of the reduplicated form of the interrogative $f e a$ 'where, which', combined with the transitive suffix -' $i$; it can occur as predicate (59) or as adverb (60):

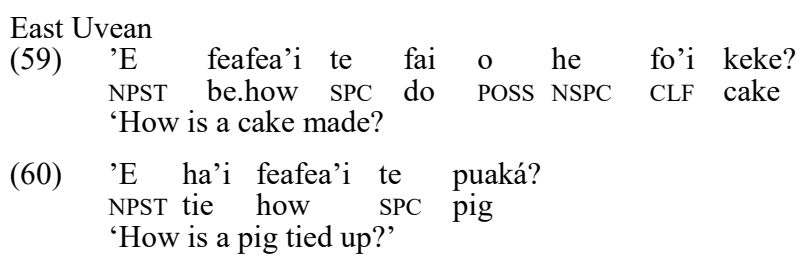


Similar manner interrogative verbs are found in Hawaiian (pehea), and Māori (pēhea, pēwhea, Williams 1971: 274). In Samoan (Mosel \& Hovdhaugen 1992: 138), the interrogative verb includes the fa' $a$ - prefix: fa'afefea, fa' apéfea, as is the case with the verbal manner demonstratives.

\section{SIMILATIVE CONSTRUCTIONS INCLUDING A STANDARD MARKER}

We have seen that most Polynesian verbal manner demonstratives are formed with the similative standard marker (-pe/pe- 'like'). Similative constructions expressing equal manner (Haspelmath \& Buchholz 1998) can include the standard marker occurring in a coordinating function, introducing the standard of comparison.

In East Futunan the conjunction pe (pête+ singular pronouns) is the standard marker, which, as we have seen in $\$ 2.2 .1$, is not identical in this language with any part of the verbal manner demonstratives $(61,62)$.

East Futunan

(61) E sa'ele a ia sakinake pe se ne'a e masaki. NPST walk ABS 3SG maybe like NSPC person NPST sick 'It seems that he walks like someone who is sick.' $\begin{array}{lllll}\text { (62) } & \text { tugolo a } & \text { Mikaele pe } & \text { se puaka. } \\ \text { NPST } & \text { snore ABS } & \text { Mikaele like } & \text { NSPC pig }\end{array}$ 'Mikaele snores like a pig.'

In the two following East Futunan sentences, the parameter is the verb fai 'do, make, build', expressing physical similarity. The use of this verb in comparative constructions is attested in other languages, but most often to express similar behaviour, as for example in French with the verb faire 'do', in expressions such as Il fait sans arrêt le singe 'He is always messing about.'

East Futunan

(63) E fai a Paulo pēte au. NPST do ABS Paulo like 1SG 'Paulo looks like me.'

$\begin{array}{lllllll}\text { (64) } & \text { E fai } & \text { le } & \text { palu } & \text { pe } & \text { se } & \text { malau. } \\ \text { NPST do } & \text { SPC } & \text { fish sp. } & \text { like } & \text { NSPC } & \text { fish.sp. }\end{array}$ NPST do SPC fish sp. like NSPC fish.sp.
'The rusty jobfish (Aphareus rutilans) resembles a squirrelfish (Adioryx sp.).'

Incidentally, the verb $f a i$ 'do' is a component of a complex comparative preposition, as we will see below.

East Futunan pe is also used as a conditional marker $(65,66)$ and a disjunctive coordinating marker (67):

East Futunan

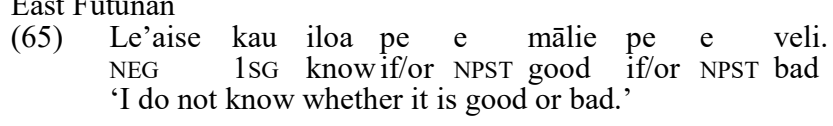


(66) E suki le gā inati pe kua moso. NPST pick SPC CLF meat if/or PFV be.cooked 'The piece of meat is pricked to see if it is cooked.'

(67) $\mathrm{Na}$ ke 'au i fea, i tai pe i 'uta? PST 2SG come STAT where STAT sea or STAT inland 'Where did you come from, from the sea or from inland?'

In Marquesan, the similative standard marker is me (68):

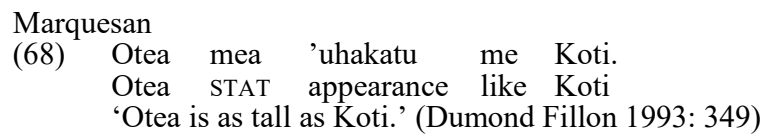

Cablitz (2006: 137) adds the following comments concerning the non-specific article he obligatorily occurring with me when the standard of comparison is a nominal phrase: "There are only two positions in which only he, but no other article can occur, i.e. 1 . with the subject of negative existential clauses, and 2 . in the comparative construction with me. In both positions the noun phrase marked by he is non-referential." (69):

Marquesan $\begin{array}{llllll}\text { (69) ...na } & \text { 'i'ima } & \text { u maho'a me he pekeheu. } \\ \text { ART.DU } & \text { RED.arm } & \text { PFV level } & \text { like } & \text { NSPC wing }\end{array}$ ...the two arms became levelled like wings (of a bird). (Cablitz 2006: 137)

This is also the case in East Futunan (61, 62, 64 above), and in Tuvaluan, according to Besnier (2000: 292) who states that "equative objects marked with me must be indefinite".

Indeed, this constraint seems to be widely attested in Polynesian languages.

More complex prepositions, such as East Futunan o fai pe/pète lit. 'do like' $(70,71)$ and East Uvean $o$ hage $\bar{e} o$ lit. 'be like as' $(72,73)$ are also used to express similarity.

East Futunan

(70) $\mathrm{E}$ se $\quad \mathrm{kai}$ lasi a a a $\quad$ o fai pēte koe.

do.like 2SG

'I do not eat as much as you do.' (Moyse-Faurie 1997: 90)

(71) Ano o fakapaku le moa o fai pe laku faka'ilo'ilo atu go COMPfry SPC chicken to.do.like POSS1SG teaching CFUGE i nānafi. STAT yesterday

'Go and fry the chicken as I taught you yesterday.'

East Uvean

(72) 'E mole kei tou mā'u'uli o hagē ko 'atatou kuí. NPST NEG REM 1PL.INCL live.PL to.be.like POSS1PL.INCL ancestor 'We do not live anymore like our ancestors did.' 
(73) 'E au 'ofa iā Soane o hagē ko hoku tehina. NPST 1SG love STAT Soane to.be.like POSS1SG brother 'I love Soane as if he was my brother.'

\section{DIRECTIONALS AND COMPARATIVE CONSTRUCTIONS}

The terms "Comparative constructions" are often used to only describe comparison of inequality (Stassen 2013), and do not include comparison of equality which is the main topic of this article. I will now mention briefly how comparison of inequality is expressed in Polynesian languages, in order to point out the main differences between these two kinds of comparative constructions. Whereas comparison of equality is mainly assumed by verbs of manner and demonstratives, comparison of inequality involves the use of deictic directionals.

According to Pawley $(1973,2003)$ and Ross (2004), the development of verbs of movement into deictic directionals was already achieved in Proto Oceanic (POc) for *mai 'come' > 'towards speaker' and *[w]atu 'go away' > 'towards addressee', 'away from speaker'. For PPn, three other directionals are reconstructed: *hake 'upward', *hifo 'downward' and *aye 'along, obliquely'. Two of these stem from verbs in POc *sake 'go upward' and *sifo 'go downward' (Ross 2004). Hence, the directional adverbs reconstructed in PPn result from the grammaticalisation of verbs:

- PPn *mai 'hither' (ventive/centripetal) < POc *mai 'come'

- PPn *atu 'thither' (centrifugal) < POc *(w)atu 'go away'

- PPn *ake 'up' < PPn *hake 'go up' < POc * sake 'go upward'

- PPn *ifo 'down' < PPn *hifo 'go down' < POc *sifo 'go downward'

Polynesian directionals are always part of comparative constructions of degree. The directional is the parameter and the static preposition $i$ is the standard marker. All four directionals occur in comparative constructions, but their distribution differs from one language to the other, even if in most cases, it follows the canonical schema, with the use of the directionals 'up' and 'down' for comparison of inequality: reflexes of PPn *hake 'go up' are used when the comparison or action denotes an increase in quantity or height ('More is up', Lakoff \& Johnson 1980: 15, 20): better, higher status, older, healthier, etc.), while reflexes of *hifo 'go down' are used when the comparison involves a decrease or a lower height or quantity. Besides, we have seen two examples with a manner verb followed by a directional, expressing an optative use (\$3.3.3).

The ventive directional (also source preposition in some Polynesian languages) happens to occur in similative constructions, as is the case at least in Tahitian. This use can be accounted for as similarity with the notion of closeness, spatial proximity $(74,75)$.

Tahitian

(74) Mai te feti'a ra 'oe te huru.

VENT SPC star ANAPH 2SG SPC appearance

'You look like a star.' (Lit. hither the star you the appearance) 
$\begin{array}{lllll}\text { (75) 'A } & \text { rave, mai } & \text { tā'oe } & \text { e } & \text { hina'aro. } \\ \text { IMP } & \text { to.do VENT } & \text { yours } & \text { IPFV } & \text { want }\end{array}$

'Do as you want.' (Lemaître 1973: 71)

In Tuvaluan, the ventive directional mai is used "when the comparison denotes or connotes the fact that the entity being compared is closer to the point of reference of the discourse than the entity forming the standard of comparison" (Besnier 2000: 218), but mai is not used for equative comparisons, which are expressed either with verbal manner demonstratives or with verbs of resemblance (ibid.: 224-227).

\section{CONCLUSION}

Polynesian languages have a rich verbal paradigm to express resemblance and similative constructions. Some of them make a clear deictic differentiation in the manner domain, and occur in different functions. The use of the numeral 'one' as predicate to express complete identity between comparees is also an interesting feature.

The number of manner demonstrative verbs has been understated by Guérin (2015: 186): "There are typically one or two MDVs in a language, even though other demonstratives usually have more contrasting forms". In all the Polynesian languages I am aware of, at least three, and in some cases four verbal manner demonstratives are present, that is as many as the basic nominal demonstratives, and showing as many deictic distinctions. The processes of lexicalization these demonstrative verbs have undergone is also noteworthy. In some languages, the original demonstrative component is barely recognisable, through its integration into the manner verb lexeme, as well as with other components, varies depending on the language.

I have found some functions not mentioned by Guérin (2015), such as optative sentences and adnominal determiners, but very few uses of verbal demonstratives in comparative constructions, or as relative markers, as is common in European languages (König 2015).

Verbal demonstratives mainly express similarity of manner but not of degree. This paper has investigated their pragmatic use (exophoric, endophoric, anaphoric, cataphoric). The manner verb expressing proximal deixis can assume most of the functions of the one expressing distal deixis, but it seems that only the proximal verb can have a prospective use, and only the distal one can have an optative/conditional use.

Finally, the use of the ventive directional to express similarity of degree, attested at least in Tahitian, is noticeable, and should be further investigated.

\section{REFERENCES}

Académie tahitienne, 1986, Grammaire de la langue tahitienne, Fare Vana'a, Tahiti.

Bataillon P., 1932, Langue d'Uvea (Wallis). Grammaire-dictionnaire uveafrançais. Dictionnaire français-uvea-anglais, Paris, Librairie orientaliste Paul Geuthner. 
Bauer W., 1997, The Reed reference grammar of Māori, Auckland, Reed Books. Besnier N., 2000, Tuvaluan. A Polynesian language of the Central Pacific, London/New York, Routledge.

Cablitz G., 2006, Marquesan: A grammar of space, Berlin/New York, Mouton de Gruyter, Trends in Linguistics, Studies and Monographs 169.

Churchward C. M., 1953, Tongan grammar, London, Oxford University Press.

Coppenrath H., \& Prevost P., 1975, Grammaire approfondie de la langue tahitienne. Papeete, Librairie Pureora.

Diessel H., 2003, The relationship between demonstratives and interrogatives. Studies in Language 27, p. 635-655.

Dixon R.M.W., 1988, A grammar of Boumaa Fijian, Chicago, University of Chicago Press.

Dixon R.M.W., 2003, Demonstratives: A cross-linguistic typology, Studies in Language 27(1), p. 61-112.

Du Feu V., 1996, Rapanui, London/New York, Routledge.

Dumond Fillon R., 1993, Eléments de grammaire fonctionnelle du marquisien, thèse de doctorat (Paris V).

Elbert S. H. \& Kawena Pukui M., 1979, Hawaiian grammar, Honolulu, University of Hawaii Press.

Greenhill S. J. \& Clark R., 2011, Pollex-Online: The Polynesian lexicon project online, Oceanic Linguistics 50(2), p. 551-559.

Grézel I., 1878, Dictionnaire futunien-français avec notes grammaticales, Paris, Maisonneuve et Cie.

Guérin V., 2015, Demonstrative verbs: A typology of verbal manner deixis, Linguistic Typology 19(2), p. 141-199.

Haspelmath M. \& Buchholz O., 1998, Equative and similative constructions in the languages of Europe, in J. van der Auwera \& D. P. O Baoill (eds), Adverbial constructions in the languages of Europe, Berlin/New York, Mouton de Gruyter, p. 277-334.

Hovdhaugen E., 2006, A short dictionary of the Vaeakau-Taumako language, Oslo, The Kon-Tiki Museum Occasional Papers vol. 11.

Hovdhaugen E., Næss A. \& Hoëm I., 2002, Pileni texts with a Pileni-English vocabulary and an English-Pileni finderlist, Oslo, The Kon-Tiki Museum Occasional Papers vol. 7.

König E., 2015, Manner deixis as source of grammatical markers in IndoEuropean languages, in C. Viti (ed.), Perspectives on historical syntax, Amsterdam/Philadelphia, Benjamins, p. 33-60.

Lakoff G. \& Johnson M., 1980, Metaphors we live by, Chicago, University of Chicago Press.

Lemaître Y., 1973, Lexique du tahitien contemporain, Paris, Office de la Recherche Scientifique et Technique Outre-Mer.

Mosel U., 2004, Demonstratives in Samoan, in G. Senft (ed.), Deixis and demonstratives in Oceanic languages, Canberra, The Australian University, Pacific Linguistics 562, p. 141-174.

Mosel U. \& Hovdhaugen E., 1992, Samoan reference grammar, Oslo, Scandinavian University Press.

Moyse-Faurie C., 1997, Grammaire du futunien, Nouméa, Centre de Documentation Pédagogique, coll. Université.

Moyse-Faurie C., 2016, Te lea faka'uvea - Le wallisien, Leuven, Peeters, Les Langues du Monde 7. 
Næss Å., 2004, Spatial deixis in Pileni, in Gunter Senft (ed.), Deixis and demonstratives in Oceanic languages, Canberra, The Australian National University, Pacific Linguistics 562, p. 81-97.

Næss Å. \& Hovdhaugen E., 2011, A grammar of Vaeakau-Taumako, Berlin/New York, de Gruyter Mouton.

Pawley A., 1966, Polynesian languages: A subgrouping based on shared innovations in morphology, Journal of the Polynesian Society 75, 1, p. 39-64.

Pawley A., 1967, The relationship of Polynesian Outlier languages, Journal of the Polynesian Society 76-3, p. 259-296.

Pawley A., 973, Some problems in Proto-Oceanic grammar, Oceanic Linguistics 12, p. $103-188$.

Pawley A., 2003, Grammatical categories and grammaticalisation in the Oceanic verb complex, in A. Riehl \& T. Savella (eds.), Cornell Working Papers in Linguistics 19, p. 149-172.

Ranby P., 1980, A Nanumea lexicon, Canberra, Department of Linguistics, Research School of Pacific Studies, The Australian National University.

Ross M., 2004, The grammaticization of directional verbs in Oceanic languages, in I. Bril \& F. Ozanne-Rivierre (eds.), Complex predicates in Oceanic language: Studies in the dynamics of binding and boundness. Berlin/New York, Mouton de Gruyter, p. 297-329.

Senft G. (ed.), 2004, Deixis and demonstratives in Oceanic languages, Canberra, The Australian National University, Pacific Linguistics 562.

Stassen L., 2013, Comparative constructions, in M. S. Dryer \& M. Haspelmath (eds.), The world atlas of language structures online, Leipzig, Max Planck Institute for Evolutionary Anthropology, p. XXXX.

Williams H. W., 1971, A dictionary of the Maori language, Wellington, A.R. Shearer, Government Printer.

Zewen F., 1987, Introduction à la langue des îles Marquises: le parler de Nuku Hiva, Papeete, Haere Po. 